\title{
Tracing biomass burning plumes from the Southern Hemisphere during the AMMA 2006 wet season experiment
}

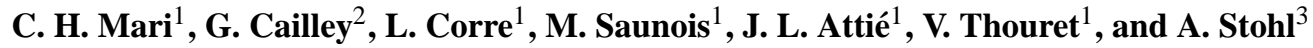 \\ ${ }^{1}$ Université de Toulouse, CNRS/INSU, Laboratoire d'Aérologie, Toulouse, France \\ ${ }^{2}$ SILOGIC, Toulouse, France \\ ${ }^{3}$ Norwegian Institute for Air Research, Kjeller, Norway
}

Received: 1 October 2007 - Published in Atmos. Chem. Phys. Discuss.: 28 November 2007

Revised: 29 May 2008 - Accepted: 10 June 2008 - Published: 24 July 2008

\begin{abstract}
The Lagrangian particle dispersion model FLEXPART coupled with daily active fire products provided by the MODIS instrument was used to forecast the intrusions of the southern hemispheric fire plumes in the Northern Hemisphere during the AMMA (African Monsoon Multidisciplinary Analysis) fourth airborne campaign from 25 July to 31 August 2006 (Special Operation Period SOP2_a2). The imprint of the biomass burning plumes over the Gulf of Guinea showed a well marked intraseasonal variability which is controlled by the position and strength of the southern hemispheric African Easterly Jet (AEJ-S). Three different periods were identified which correspond to active and break phases of the AEJ-S: 25 July-2 August (active phase), 3 August-8 August (break phase) and 9 August-31 August (active phase). During the AEJ-S active phases, the advection of the biomass burning plumes out over the Atlantic ocean was efficient in the mid-troposphere. During the AEJ$S$ break phases, pollutants emitted by fires were trapped over the continent where they accumulated. The continental circulation increased the possibility for the biomass burning plumes to reach the convective regions located further north. As a consequence, biomass burning plumes were found in the upper troposphere over the Gulf of Guinea during the AEJ-S break phase. Observational evidences from the ozonesounding network at Cotonou and the carbon monoxide measured by MOPITT confirmed the alternation of the AEJ-S phases with low ozone and $\mathrm{CO}$ in the mid-troposphere over the Gulf of Guinea during the break phase.
\end{abstract}

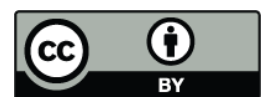

Correspondence to: C. H. Mari (marc@aero.obs-mip.fr)

\section{Introduction}

Biomass burning has long been recognized as a significant source of reactive species such as $\mathrm{CO}$, hydrocarbons and $\mathrm{NO}_{\mathrm{x}}$ and aerosols, which play an important role in the chemistry and radiative budget of the troposphere (Crutzen and Andreae, 1990; Marufu et al., 2000; Thompson et al., 2001; Andreae and Merlet, 2001; Aghedo et al., 2007). The radiative forcings of biomass burning emissions can be contrasted depending on the timescale considered. Reducing biomass burning emissions can cause a short-term warming but a long-term cooling from reducing $\mathrm{CO}_{2}$ (Jacobson, 2004; Naik et al., 2007). Naik et al. (2007) also reported large regional differences in the radiative response depending on the biomass availability and meteorological conditions. In Africa, human activities are the primary cause of biomass burning, including forest clearance, savanna burning (Delmas et al., 1999), restoration and land management (Crutzen and Andreae, 1990). It is known that the frequencies of wildfires over Africa generally follow a clear seasonal cycle. African biomass burnings occur during the dry seasons - late November to early March in the Northern Hemisphere and July to October in the Southern Hemisphere (Marenco et al., 1990; Giglio et al., 2006; Palacios-Orueta et al., 2004; Ito et al., 2007). However, the frequency and intensity of fires is also dependent on meteorological and climatic conditions. In tropical areas, temperature and length of the dry season can vary from one year to the other with dramatic impact on the fire characteristics (Palacios-Orueta et al., 2004).

In regions downwind of biomass burning emissions, high ozone concentrations have been reported in the literature. Several studies have discussed the biomass burning origin of the ozone maximum observed over the remote South Atlantic ocean during the Northern Hemisphere dry season (Jonquières et al., 1998; Thompson et al., 2000; Martin

Published by Copernicus Publications on behalf of the European Geosciences Union. 
et al., 2002; Edwards et al., 2003; Jourdain et al., 2007; Sauvage et al., 2007a). The transport pathways taken by these biomass burning plumes out over the adjacent Atlantic ocean were further discussed by Chatfield et al. (2002), Edwards et al. (2003) or Sinha et al. (2004) among others. On the contrary little has been published on the ozone features over the Northern Hemisphere during the southern hemispheric dry season. Jenkins et al. (1997) evoked the possibility for ozone production over the Atlantic ocean during the Northern Hemisphere wet season (June-August). The authors pointed out the transport of $\mathrm{O}_{3}$ and precursors by south-southeasterly winds in the PBL toward the regions of deep convection. A recent study by Sauvage et al. (2005) connected the mid-tropospheric ozone maxima observed in cities near the Gulf of Guinea to biomass burning plumes originating from the opposite dry-season hemisphere. This new finding was the major motivation for the present study in the framework of the AMMA fourth airborne campaign from 25 July to 31 August 2006 (Mari and Prospero, 2005; Redelsperger et al., 2006). During this period, occurences of biomass burning plumes over West Africa were observed on board the aircrafts with elevated concentrations of acetonitrile, ozone and $\mathrm{NO}_{\mathrm{x}}$ subsequently in the lower and upper troposphere (Real et al., 2007b; Reeves et al., 2007) and by the ozonesounding network in Cotonou (Saunois et al., 2007). These occurences showed a large temporal variability (Reeves et al., 2008 ${ }^{1}$; Janicot et al., 2008 ${ }^{2}$ ). This paper thus aims at providing the basic understanding of the variability of the biomass burning plumes occurence over West Africa and helps the interpretation of the data sampled during the wet season 2006.

In this study, we use daily simulations of the transport of biomass burning tracers over the Gulf of Guinea in order to identify the pathways of pollution originating from the Southern Hemisphere over timescales up to 10 days after their emission. The objective is to document the pathways for the interhemispheric transport of biomass burning plumes and relate them to the meteorological conditions. In Sect. 2, we describe the meteorological features over West and Central Africa. Next, in Sect. 3, we provide a description of the Lagrangian model used. In Sect. 4 we use the Lagrangian model to examine the intraseasonal variability of the biomass burning plumes. In Sect. 5, observational evidences of sum-

\footnotetext{
${ }^{1}$ Reeves, C., Ancellet, G., Borbon, A., Cairo, F., Law, K., Mari, C., Methven, J., Schlager, H., Thouret, V.: Chemical characterisation of the troposphere over West Africa during the monsoon period as part of AMMA, in preparation, 2008.

${ }^{2}$ Janicot, S., Ali, A., Asencio, N., Berry, G., Bock, O., Bourles, B., Caniaux, G., Chauvin, F., Deme, A., Kergoat, L., Lafore, J.-P., Lavaysse, C., Lebel, T., Marticorena, B., Mounier, F., Redelsperger, J.-L., Ravegnani, F., Reeves, C., Roca, R., de Rosnay, P., Sultan, P., Thorncroft, C., Tomasini, M., Ulanovsky, A., and ACMAD forecasters team: Large-scale overview of the summer monsoon over West and Central Africa during the AMMA field experiment in 2006, Ann. Geophys., submitted, 2008.
}

mer wet-season fires plumes are presented from the MOPITT and AMMA ozonesounding network. Finally, in Sect. 6, we discuss the potential impact of the major transport pathways and timescale of the biomass burning plumes on the tropospheric ozone chemistry.

\section{Meteorological features over West and Central Africa}

The West African Monsoon (WAM) is characterised by the migration of zonally banded rainfall from the Guinea coast to the Sahel and back again, resulting in two rainy seasons per year in the south and one in the north (see Hall and Peyrillé (2006) for a complete review of the WAM dynamics). The rainbelt is the loci of disturbances that are dynamically linked to the midlevel northern African Easterly Jet (hereafter AEJ-N), a mid-tropospheric flow with peak amplitude of around $10-20 \mathrm{~ms}^{-1}$ at an altitude of around $600-700 \mathrm{hPa}$ and a latitude of around $15^{\circ} \mathrm{N}$ in August. The AEJ-N is known to be in approximate thermal wind balance with the thermodynamic contrasts from the Guinea coast to the Sahara (Burpee, 1972; Parker et al., 2005). Its structure and strength are sensitive to the dust aerosol availability over the Sahel and Sahara regions (Tompkins et al., 2005; Chaboureau et al., 2007). Apart from its role and origin in the balance of the WAM thermodynamic state, the AEJ-N has a meteorological impact on the patterns of rainfall in the Sahel. Its vertical shear is important for the growth of longlived mesoscale convective systems which provide most of the observed rainfall in West Africa (Houze and Betts, 1981; Redelsperger et al., 2002). Its potential vorticity and lowlevel temperature contrasts are important for African Easterly wave development.

In contrast to the abundant literature on the West African climate, only a few studies have been devoted to the equatorial Africa where the fires occur during the boreal wet season. The understanding of meteorological processes in this region is weak. For example, state-of-art satellite algorithms overestimate rainfall in this region by a factor of 2 or 3 (Nicholson and Grist, 2003), suggesting a poor understanding of rain processes in this region. Biomass burning aerosols have also been suggested by Rosenfeld (1999) and Andreae et al. (2004) to suppress convective rainfall. Burpee (1972) first described the existence of a mid-tropospheric Southern Hemisphere easterly jet (hereafter AEJ-S). The location and strength of the AEJ-S was further confirmed by the recent study of Nicholson and Grist (2003), based on NCEP reanalysis and radiosonde data. The authors showed the persistance of the northern and southern hemispheric jets during most months. In contrast to West Africa, central Africa experiences a strongly bimodal annual cycle, coincident with both the northward and southward passage of the ITCZ. Peak rainfall tends to be in the transition seasons. Figure 1 shows the mean zonal winds for two sectors derived from ECMWF reanalysis for 25 July to 31 August. The western sector 

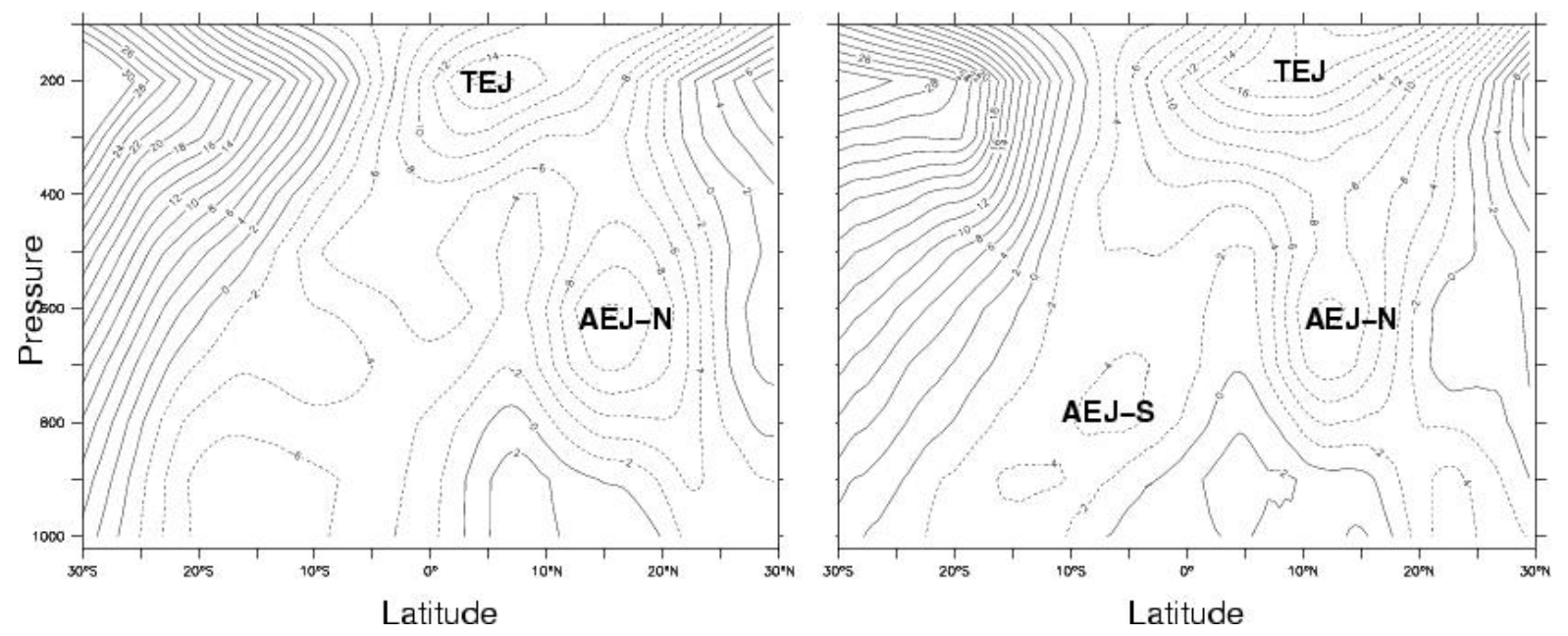

Fig. 1. Latitudinal cross section of ECMWF mean zonal wind speed $\left(\mathrm{m} \mathrm{s}^{-1}\right)$ (a) for 25 July to 31 August, averaged between $30^{\circ} \mathrm{W}$ and $10^{\circ} \mathrm{E}$, (b) for 25 July to 31 August, averaged between 10 and $30^{\circ} \mathrm{E}$.

$\left(30^{\circ} \mathrm{W}-10^{\circ} \mathrm{E}\right)$ includes both the continent and the Atlantic ocean to the south, while the eastern $\left(10-30^{\circ} \mathrm{E}\right)$ extends only through the continent and includes equatorial Africa. Three easterly jets are evident over West Africa, an upper tropospheric easterly jet (the TEJ) around $200 \mathrm{mb}$ and two midtropospheric jets near $650 \mathrm{mb}$ (the AEJ-N and AEJ-S). During the Northern Hemisphere (NH) summer, the AEJ-N is located around $15^{\circ} \mathrm{N}$, with core speed higher than $10 \mathrm{~ms}^{-1}$. The altitude of the core is around $600 \mathrm{mb}$. The AEJ-S is more pronounced in the eastern (continental) sector. AEJ-S core speed lies between 4-6 ms ${ }^{-1}$ over the continent. Hence, it is weaker than the AEJ-N. Its position is around $5^{\circ} \mathrm{S}$ and $700 \mathrm{mb}$. The oceanic part of the AEJ-S has a less marked signature on a monthly mean basis. The existence of the AEJ-S was also confirmed by Zhang et al. (2006) using sounding data at Luanda $\left(8^{\circ} \mathrm{S}\right)$. They found that the AEJ-S does not extend far into the tropical Atlantic ocean at this latitude. It has generally been accepted (Thorncroft and Blackburn, 1999) that the origin of the AEJ-N is basically the temperature gradient induced by the contrast between the Sahara and the humid Guinea coast region to the south. Nicholson and Grist (2003) showed that the origin of the AEJ-S is also related to the surface temperature gradient. In this case, the temperature contrast is produced by semiarid regions of the Southern Hemisphere compared to the subhumid, perenially vegetated lands to the north.

Figure 2 resumes the dynamical features over West Africa during the studied period, between 25 July and 31 August, 2006. Both the AEJ-N and AEJ-S are present. The AEJ$\mathrm{S}$ has a well defined core over the continent at $5^{\circ} \mathrm{S}$. The oceanic part of the AEJ-S is found around the equator. The AEJ-N is stronger with core speed higher than $12 \mathrm{~ms}^{-1}$. It is interesting to note that the region affected by convective clouds was located roughly between the two AEJs, approx-

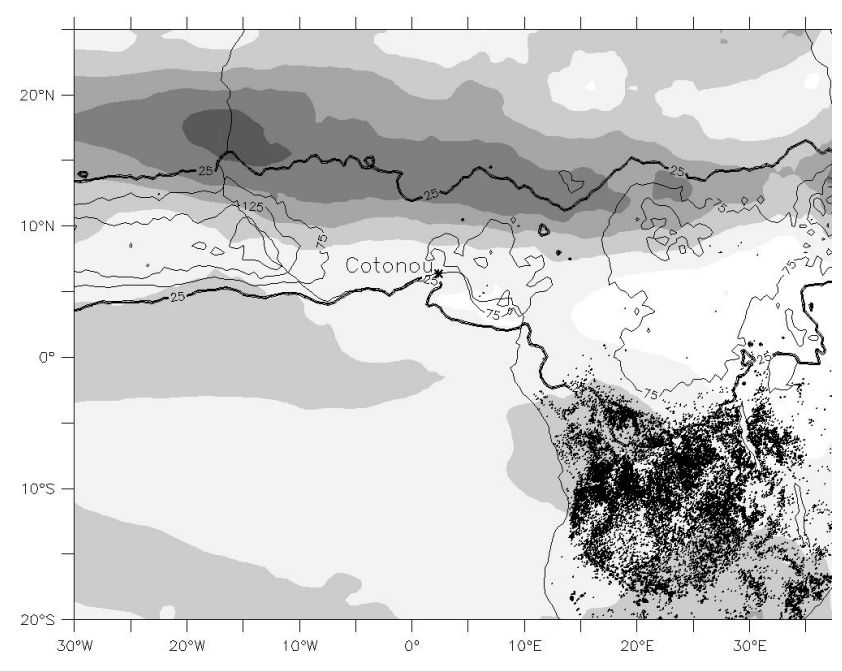

Fig. 2. Accumulated convective precipitation (isolines), in $\mathrm{m}$, and mean wind speed at $700 \mathrm{mb}$ (shaded contours), in $\mathrm{m} / \mathrm{s}$, from the ECMWF re-analysis from 15 July to 31 August 2006. MODIS fires with a confidence level equal to 100 are represented by the dots.

imately between the coast and $15^{\circ} \mathrm{N}$. Continental convection reaches southern hemispheric latitudes during this period. The dynamics during the studied period is consistent with the August WAM climatology described by Nicholson and Grist (2003).

\section{Model description}

The model around which the GIRAFE-FLEXPART (reGIonal ReAl time Fire plumes) tool has been built is the Lagrangian particle dispersion model FLEXPART (Stohl et al., 1998a; Stohl et al., 1998b; Stohl et al., 2005). FLEXPART 


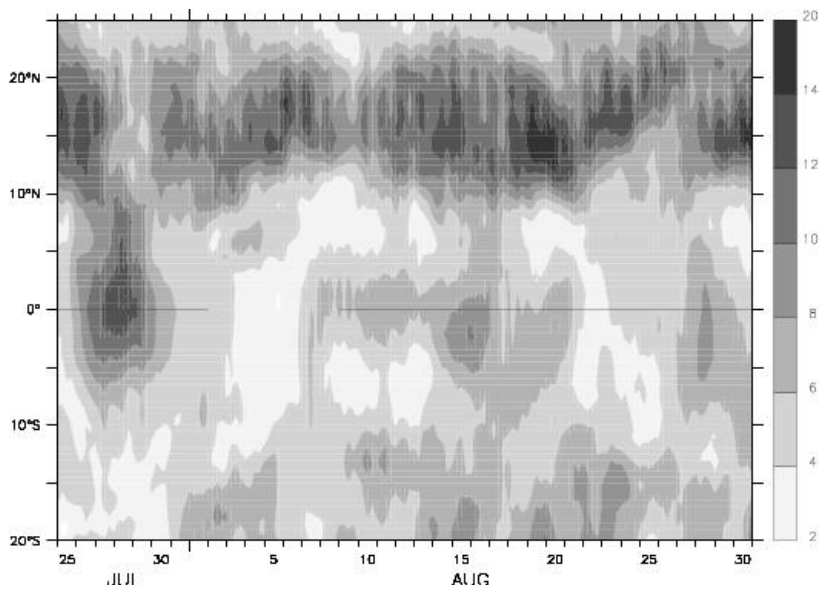

Fig. 3. Time-latitude evolution of mean wind speed in $\mathrm{m} / \mathrm{s}$ at $700 \mathrm{mb}$, averaged between $30^{\circ} \mathrm{W}$ and $10^{\circ} \mathrm{E}$ from the ECMWF reanalysis from 25 July to 31 August 2006. Solid lines indicate the active AEJ-S phases.

simulates the transport and dispersion of linear tracers by calculating the trajectories of a multitude of particles. The model treats advection and turbulent diffusion by calculating the trajectories of a multitude of particles. Stochastic fluctuations, obtained by solving Langevin equations (Stohl and Thompson, 1999) are superimposed on the grid-scale winds from the ECMWF dataset to represent transport by turbulent eddies, which are not resolved. To account for subgrid scale convective processes, FLEXPART was equipped with the convection scheme developped by Emmanuel and Zivkovìc-Rothman (1999).

In the framework of the AMMA program, FLEXPART was coupled with daily emissions of passive tracers by fires. Ten-day forecasts were provided operationally on the AMMA Operation Center website http://aoc. amma-international.org/. For the identification of the areas that are affected by biomass burning, we use the Moderate Resolution Imaging Spectroradiometer (MODIS) daily active fire product (Justice et al., 2002; Giglio et al., 2003). The fires are identified based on the temperature at wavelength $4 \mu \mathrm{m}$ compared to that at $11 \mu \mathrm{m}$. The active fire product includes a confidence index. Only the hot spots with a $100 \%$ confidence level were retained for the emission distribution.

The configuration of the GIRAFE-FLEXPART model was determined by the forecasting constraints during AMMA. Once identified, the hot spots are mapped on the ECMWF model grid $(50 \mathrm{~km} \times 50 \mathrm{~km})$. An inert passive tracer in each grid cell containing at least one hot spot is represented by 1000 particles. This approach allows to save computational time by considering only one tracer per grid point of the dynamical model. However, single detections which are often wrong detections (e.g. hot spots due to gas flares, etc.) will be considered equally to grid cells with many detections. This hypothesis thus restrains the discussion on the concentration levels of the passive tracer. Particles were released during $48 \mathrm{~h}$ at a constant unity rate $(1 \mathrm{~kg} / 48 \mathrm{~h})$ from the surface to $3 \mathrm{~km}$ above ground and then carried over 10 days. The choice of the injection height was later confirmed by Labonne et al. (2007). These authors estimated the range of top height of the aerosol layers from the CALIPSO spaceborne lidar between 3 and $4.5 \mathrm{~km}$ during July and August 2006 over South Africa. New simulations were started every day during AMMA and the passive tracer was reinitialized to zero for each new simulation. It is important to note that the model set up is different from the previous works using FLEXPART to track biomass burning plumes. Wiedinmyer et al. (2006) or Stohl et al. (2007) for example followed a more formal approach in which they considered an area burned per hot spot and the use of appropriate emissions factors to get carbon monoxide concentrations. In the following, only the transport of the smoke plumes is discussed as the emissions were arbitrary chosen to unity. The particles represent a conservative tracer that behaves purely passively; that is, no chemical processes and no deposition are simulated. Figure 2 shows the position of the fires detected by MODIS with the maximum confidence level between 15 July and 31 August. During this period, the fires occured constantly in the same region, roughly between $30^{\circ} \mathrm{S}$ and the equator and between 10 and $40^{\circ}$ E. Fires were limited to the north by the convective clouds associated with the ITCZ. From 15 July to 21 August, the satellite overpassed the region approximately between 07:30 and 13:30 UTC and between 19:30 and 01:00 UTC. According to Giglio et al. (2007), the fire activity over West Central Africa peaks around 14:00 UTC. Consequently, the number of fire detections may be underestimated and it may be that the model misses source grid points. However, because of the regridding procedure, the impact on the plume trajectories should remain limited.

\section{Intraseasonal variability of summer wet-season fire plumes}

Figure 3 shows the time-latitude evolution of the wind speed derived from the ECMWF re-analysis and averaged between $30^{\circ} \mathrm{W}$ and $10^{\circ} \mathrm{E}$. These longitudes cross the continent over West Africa and the Gulf of Guinea in the Southern Hemisphere. The AEJ-N is clearly visible around $15^{\circ} \mathrm{N}$ during all the period. In contrast, the position and strength of the AEJ-S show high intraseasonal variability with successive active and break phases. During a first period (25 July-2 August), the AEJ-S is strong and present over the whole Gulf of Guinea. Maximum wind speed reaches $10 \mathrm{~m} \mathrm{~s}^{-1}$ over the sea. High wind speeds are found up to $15^{\circ} \mathrm{S}$ in the Southern Hemisphere whereas both jets confound in the Northern Hemisphere. From 3 August to 9 August, there is no signature of the AEJ-S in the northern and Southern Hemispheres. From 10 August, the AEJ-S regains strength and a well-defined core of strong wind speed is located from the 
equator to $10^{\circ} \mathrm{S}$. Over the continent (not shown), the jet intensifies until the end of August. The oceanic part of the AEJ-S weakens after 20 August and reintensifies after 26 August. By the end of August, the AEJ-S is well defined over the Southern Hemisphere Central East Africa and Atlantic regions. During the first active phase described above (25 July-30 July), fire plumes are simulated over the Gulf of Guinea with a latitudinal extent up to $2000 \mathrm{~km}$ (Fig. 4). It is worth noting that the discontinuities in the model outputs in Fig. 4 are due to the reinitialization of the tracer. For one given day, only the plume started from 5 to 10 days before is shown. Figure 4 shows the sum of these contributions for every given days. From 31 July, mixing ratios of the fire tracer decrease and the Gulf of Guinea remains free of fire pollution until 10 August when the AEJ-S strengthens. After $12 \mathrm{Au}-$ gust, the outflow of fire plumes persists until the end of the month in phase with the AEJ-S activity. From Fig. 4, it can be concluded that, except during the AEJ-S break phase, fire pollution is present continuously between $10^{\circ} \mathrm{S}$ and $5^{\circ} \mathrm{N}$. To the south, the fire plumes can be advected up to $20^{\circ} \mathrm{S}$. Four episodes of that type were predicted during July and August 2006. The southern latitudinal extension of the plume is governed by the position of the subtropical anticyclone in the middle troposphere (between 10 and $20^{\circ} \mathrm{S}$ ). If the axis of the subtropical anticyclone in the middle troposphere is above the coasts of the Gabon, Congo or Democratic republic of Congo, easterly and southeasterly winds occur north of the axis. These enhanced winds are located above or near the source regions and favor the shift in the advection of the plumes toward the southern latitudes.

\section{Observational evidences of summer wet-season fires plumes}

The first evidences of southern hemispheric fire intrusions were described by Sauvage et al. (2005) based on the MOZAIC profiles over Africa. These authors showed that elevated concentrations of ozone observed between 600$700 \mathrm{mb}$ over West Africa during the wet season originated from fires in the Southern Hemisphere. In the framework of the AMMA campaign, regular ozonesoundings were performed at Cotonou, Benin (Fig. 5). Cotonou is located near the Gulf of Guinea and therefore can be influenced by the pollution from the southern hemispheric fires. A complete description of the ozonesoundings and the characterization of the origins of the ozone maxima will be described in a companion paper (Thouret et al., 2008 3 ). Figure 5 shows three ozone profiles measured during the AMMA experiment. The marking point is the strong variation of the ozone profile be-

\footnotetext{
${ }^{3}$ Thouret, V., Saunois, M., Mari, C., Corre, L., Picart, J., Mariscal, A., Nedelec, P., Minga, A., Solete, A., and Agbangla, D.: Characterisation of air masses over Cotonou during the wet season: influence of biomass burning and local pollution, in preparation, 2008.
}

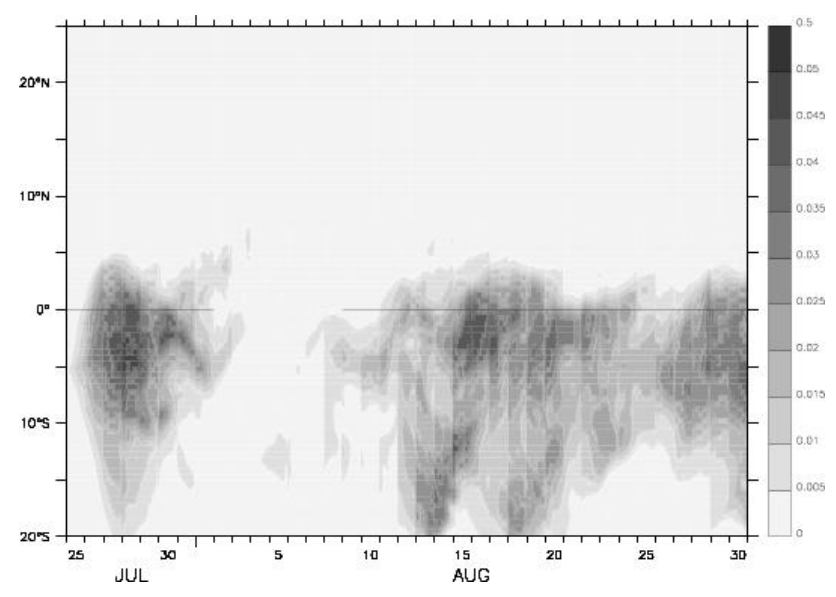

Fig. 4. Time-latitude evolution of fire passive tracer $\left(\mathrm{ng} / \mathrm{m}^{3}\right)$ at $3000 \mathrm{~m}$, averaged between $30^{\circ} \mathrm{W}$ and $10^{\circ} \mathrm{E}$ from the GIRAFEFLEXPART 5 to 10 days simulations from 25 July to 31 August 2006. Solid lines indicate the active AEJ-S phases (see also Fig. 3).

tween 2 and $4 \mathrm{~km}$. The ozone peaks on 25 July and on 17 August correspond to the active phases of the AEJ-S when the Gulf of Guinea is under the influence of the fire plumes. On the contrary, the low values of ozone observed on $3 \mathrm{Au}-$ gust coincide with the AEJ-S break phase, when the Gulf of Guinea is free of biomass burning pollution. During the actives phases, the ozone mixing ratios are more than doubled (80-90 ppbv) compared to the background values (30$40 \mathrm{ppbv})$.

Satellites also provide interesting information on the biomass burning emissions fate. MOPITT measurements are performed in eight nadir-viewing spectral channels using the gas correlation technique. Detailed description of the instrument and measurement technique can be found in Drummond and Mand (1996), Pan et al. (1998) and Edwards et al. (1999). The MOPITT CO data consist of total column and vertical profiles of volume mixing ratio that are retrieved at seven pressure levels (surface, 850, 700, 500, 350, 250 and $150 \mathrm{hPa}$ ), with a horizontal resolution of $22 \times 22 \mathrm{~km}^{2}$. Global coverage is accomplished in 3 to 4 days and data are available from March 2000 to present. In this work, we focus on the $\mathrm{CO}$ mixing ratio profiles from data Version 3 at $700 \mathrm{mb}$. Figure 6 shows the $\mathrm{CO}$ mixing ratios at $700 \mathrm{mb}$ as a function of latitude and time. White areas on these plots indicate the locations of missing data mostly representative of persistent clouds over the days sampled. The intraseasonal variability of the biomass burning plume export is clearly visible in Fig. 6. During the first and second active periods, the MOPITT instrument observed large plumes of $\mathrm{CO}$ over the gulf of Guinea. On the contrary, the second period shows a minimum of $\mathrm{CO}$ mixing ratios in agreement with the ECMWF wind speed and GIRAFE-FLEXPART intraseasonnal changes. 

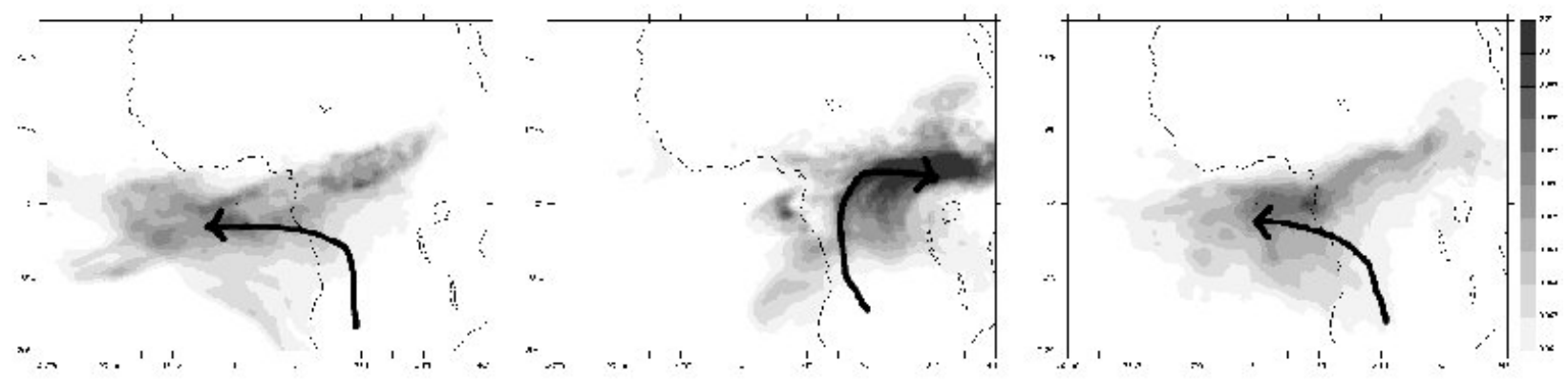

Fig. 5. Fire passive tracer $\left(\mathrm{ng} / \mathrm{m}^{3}\right)$ with predominant pathways at $3000 \mathrm{~m}$ from the GIRAFE-FLEXPART 5 to 10 days simulations averaged from (left) 25 July to 02 August 2006, (middle) 03 August to 08 August 2006 and (right) 09 August to 31 August 2006

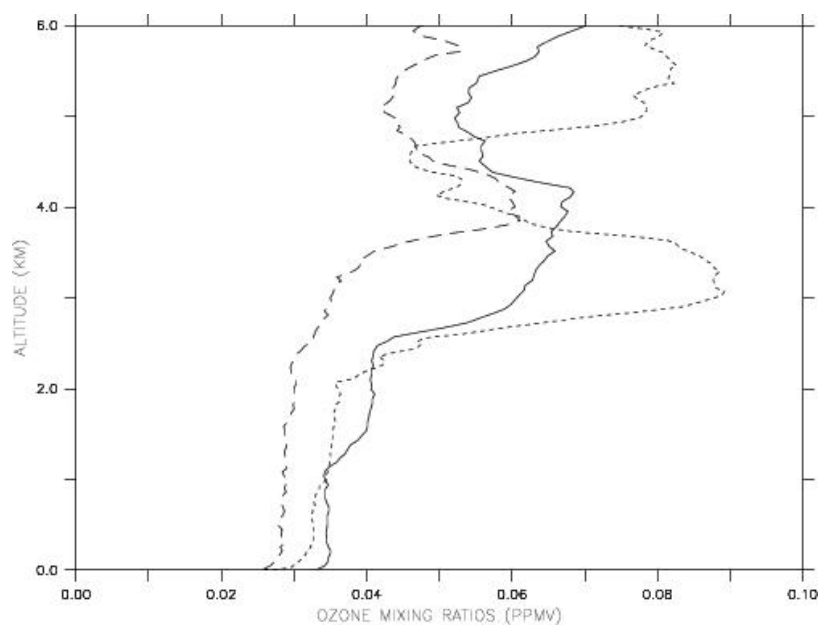

Fig. 6. Ozone mixing ratios measured at Cotonou $\left(6.21^{\circ} \mathrm{N}\right.$, $2.23^{\circ} \mathrm{E}$ ) in ppmv on 25 July (solid line), 3 August (dashed line) and 17 August (dotted line).

\section{Discussion}

The difference in the observed ozone peaks between 25 July and 17 August can be explained by the enrichment of the air masses during the break phase. From 3 to 9 August, the westward propagation is suppressed. Fire plumes recirculate and accumulate pollutants over the continent. The sudden shift of AEJ-S activity around 10-11 August leads to the westward transport of these airmasses. It is interesting to note that the AEJ-S break phase prevents the westward advection of fire pollutants but favors the injection at higher altitudes. Figure 7 shows several events of injection in the upper troposphere $(12 \mathrm{~km}$ altitude). The upper tropospheric intrusions are particularly well marked during the AEJ-S break phase. During the break phase, airmasses are retained over the continent and the probability for these airmasses to reach the regions affected by continental deep convection increases (see Fig. 2). The coincidence of biomass burning and cloud convection was proposed as a key mech- anism for the export of biomass burning emissions far away from the source regions (Krishnamurti et al., 1993; Chatfield et al., 1996; Pickering et al., 1996; Folkins et al., 1997; Jenkins et al., 1997; Trentmann et al., 2006; Sauvage et al., 2007a; Sauvage et al., 2007b) with potential intrusions into the upper troposphere and stratosphere (Fromm and Servranckx, 2003; Jost et al., 2004). Other mechanisms have been proposed for the vertical transport of biomass burning emissions: convergence between the baroclinic low-level circulations associated with the AEJ-S and the equatorward branch of the Hadley cell (Sauvage et al., 2007c) and the vertical turbulent mixing favored by the intertropical interoceanic front (Chatfield et al., 1996; Bachmeier and Fuelberg, 1996; Delmas et al., 1999). Labonne et al. (2007) have shown that the biomass burning products vertical extent is generally capped by boundary layer inversion height and that direct injection of fire pollutants to the free troposphere are unlikely. From this study, we can conclude that the vertical transport associated with deep convection is favored during and shortly after the AEJ-S break phases. During periods of active AEJ-S, a lower vertical transport may occur preferentially in the convergence zones although this can not be deduced from the present study for which an injection height is prescribed, independently from the boundary layer properties. Matichuk et al. (2003) tested the sensitivity of their model result to the injection height. The base model with emissions below the planetary boundary layer height and subsequent mixing within the PBL gives the best results. If smoke is emitted above the PBL, the model may maintain an artificial smoke layer. So it is possible that when GIRAFE-FLEXPART emits fire pollutants above the boundary layer height, the model creates fake layers in the middle troposphere.

In this work, we do not consider the diurnal cycle of the fires. Eck et al. (2003) observed large average diurnal variations of aerosol optical thickness over southern Africa which they attribute to large diurnal trends in fire counts that peak in midafternoon. However for all sites located downwind from the fire regions there was little average diurnal trend observed as the aerosol transport is not strongly influenced by diurnal cycles. Recently, Giglio et al. (2007) proposed a 


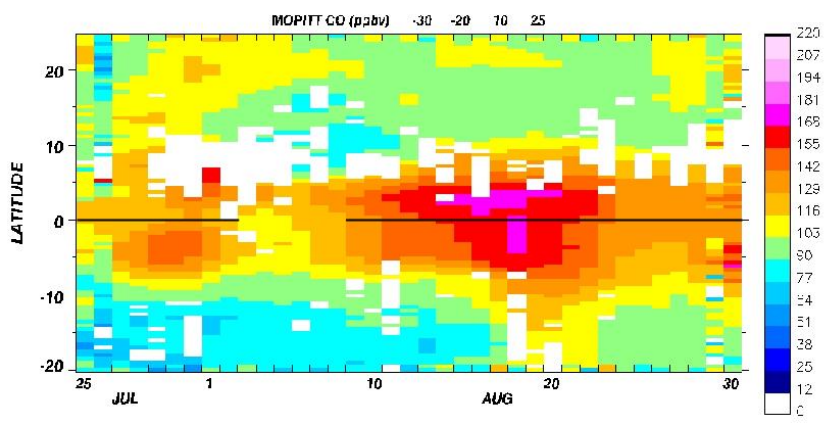

Fig. 7. CO mixing ratios, in ppbv, at $700 \mathrm{mb}$ from the TERRAMOPITT instrument as a function of latitude and time and averaged between $-30^{\circ} \mathrm{W}$ and $10^{\circ} \mathrm{E}$.

characterization of the tropical diurnal fire cycle using satellite information. The authors show that fires over Central Africa experience a great diurnal cycle with peak activity around 15:00 UTC and suppressed nighttime fire activity. Matichuk et al. (2007) found low sensitivity of the vertical extension profiles simulated by their model to the diurnal cycle of the fires. The emissions can stay near the surface at night but are quickly mixed throughout the boundary layer during the day.

It is not straightforward to assess the potential impact of these fire plumes on the ozone production from the present study which only treats the transport of a non reactive tracer. We would expect different ozone production rates from the different scenarii described above, depending of the AEJ-S phases. During the TRACE-A experiment over Brazil and South Africa in October, Pickering et al. (1996) calculated an ozone postconvective formation rate around 7-8 ppbv/day in a biomass burning perturbed region. Chatfield et al. (1996) found no net production of ozone in their simulations of southern Africa advected fire plumes. They even found a slow decrease of ozone ( 1 ppbv/day) in the low altitudes whereas Jacob et al. (1996) found an ozone production at higher levels in the upper troposphere which they explain by additional $\mathrm{NO}_{\mathrm{x}}$ from lightning. It is expected that the transport of the smoke by convective clouds is accompanied by fast significant changes in smoke chemistry. The large influence of OVOC demonstrated by Mason et al. (2001) for example will be strongly altered if the OVOC concentrations are changed by cloud processing. During TRACE-A, convective clouds were often close to the biomass burning regions which was less frequent during the AMMA summer experiment. Jenkins et al. (1997) have discussed the potential ozone production associated with the fires over Africa for different periods. The authors stated that the impact on $\mathrm{O}_{3}$ production over the ocean would be limited during the JuneJuly-August period because $\mathrm{O}_{3}$ and its precursors may be destroyed by photolysis, surface deposition and other chemical reactions because of the thousands of kilometers between the fires and the regions of deep convection. On the contrary,

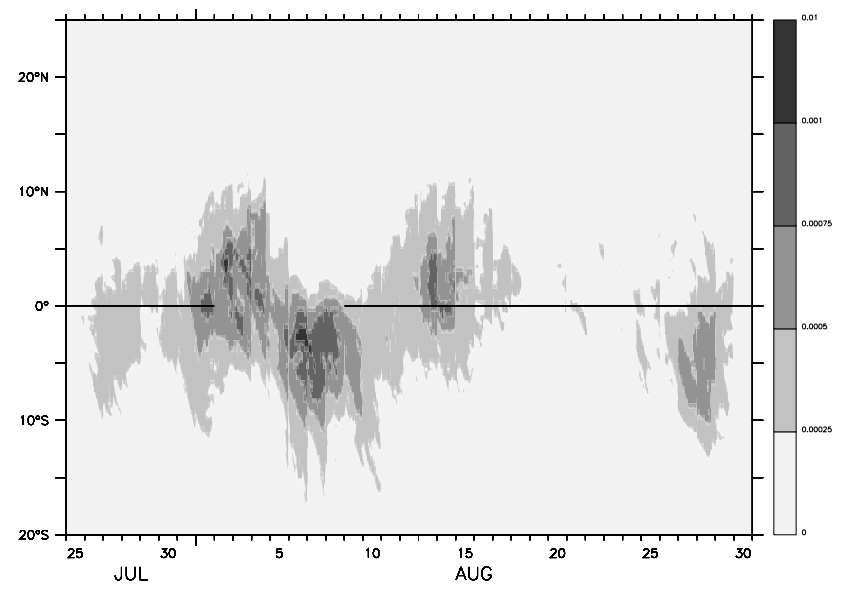

Fig. 8. Same as Fig. 4 but at $12000 \mathrm{~m}$.

this study shows that the AEJ-S can efficiently transport fresh biomass burning plumes out over the ocean, thus providing a scenario favorable to ozone production over the Atlantic ocean during the wet season. Real et al. (2007a) found an ozone increase in a boreal forest fire plume observed in the middle latitudes by 17 ppbv over 5 days. Assuming that the observed profile on 3 August gives the background mixing ratios of ozone in the middle troposphere $(25 \mathrm{ppbv})$ and assuming that the airmass age is 10 days, the increase of ozone is about $35 \mathrm{ppbv}$ for 25 July and $55 \mathrm{ppbv}$ for 17 August. The values are of the same order of magnitude or higher than those derived from Real et al. (2007a). The complexity of the chemical reactions inside biomass burning plumes as observed with new techniques (Yokelson et al., 2003) would require a complete study which is out of the scope of this paper. Lagrangian or box model approaches like the ones developped by Jost et al. (2003) or Real et al. (2007a) are now required to assess the ozone budget in the african fire plumes in the light of the different scenarii proposed here.

\section{Conclusions}

This paper describes a forecasting tool that has been developped to predict the intrusions of the southern hemispheric fire plumes in the Northern Hemisphere during the AMMA fourth airborne campaign (Special Operation Period 2_a2). The model system is based on the Lagrangian particle dispersion model FLEXPART and daily active fire products provided by the MODIS instrument. The paper presents results of simulations of passive tracer transport from 25 July to 31 August 2006. Biomass burning tracers were emitted mainly over Central Africa during the studied period. The print of the biomass burning plumes over the Gulf of Guinea showed a well marked intraseasonal variability. The latitudinal progression of the biomass burning plumes to the north was limited by the northern hemispheric African Easterly Jet. 
Several episodes of intrusions up to $20^{\circ} \mathrm{S}$ were favored by the continental position of the subtropical anticyclone in the midtroposphere. The export of the biomass burning plumes out over the Atlantic ocean was controlled by the existence and strength of the southern hemispheric AEJ. This jet is located around $5^{\circ} \mathrm{S}$ and $700 \mathrm{mb}$. The origin of the AEJ-S was shown by Nicholson and Grist (2003) to be the surface temperature gradient between the semiarid regions of the Southern Hemisphere and the subhumid vegetated lands to the north. The AEJ-S is weaker than the AEJ-N and, contrary to the persistent AEJ-N, shows a strong intraseasonal variability. Three different periods were identified which correspond to active and break phases of the AEJ-S: 25 July-2 August (active phase), 3 August-9 August (break phase) and 10 August-31 August (active phase). During the AEJ-S active phases, the advection of the biomass burning plumes was efficient in the mid-troposphere. During the AEJ-S break phases, pollutants emitted by fires are trapped over the continent where they accumulate. The continental recirculation increases the possibility for the biomass burning plumes to reach the convective regions located further north. As a consequence, simulated biomass burning plumes are found in the upper troposphere over the Gulf of Guinea during the AEJ-S break phase. This study clearly emphasizes the role of the AEJ-S in the transport of the southern hemispheric biomass burning plumes during the summer wet-season. The origins of the intraseasonal variability of the AEJ-S is an open question that deserves a comprehensive study over a larger period. The quantitative assessment of the ozone formation in these biomass burning plumes needs to be further investigated with models which include the complexity of the chemical reactions in a smoke environment. The ozone production should vary dramatically depending of the meteorological conditions associated with the active and break phases of the AEJ-S.

Acknowledgements. This work was funded by the french APIAMMA. Based on an French initiative, AMMA was built by an international scientific group and is currently funded by a large number of agencies, especially from France, the United Kingdom, the United States, and Africa. It has been the beneficiary of a major financial contribution from the European Communities Sixth Framework Research Programme. Detailed information on scientific coordination and funding is available on the AMMA International Web site at www.amma-international.org. The development of the GIRAFE-FLEXPART model was supported by the ETHER consortium. The author(s) wish to acknowledge use of the Ferret program for analysis and graphics in this paper. Ferret is a product of NOAA's Pacific Marine Environmental Laboratory. (Information is available at http://ferret.pmel.noaa.gov/Ferret/).

Edited by: P. Formenti

\section{References}

Aghedo, A. M., Schultz, M. G., and Rast, S.: The influence of African air pollution on regional and global tropospheric ozone, Atmos. Chem. Phys., 7, 1193-1212, 2007, http://www.atmos-chem-phys.net/7/1193/2007/.

Andreae, M. O. and Merlet, P.: Emission of trace gases and aerosols from biomass burning, Global Biogeochem Cy., 15, 4, 955-966, 2001.

Andreae, M. O., Rosenfeld, D., Artaxo, P., Costa, A., Frank, G. P., Longo, K. M., and Da Silva, M. A.: Smoking rain clouds over the Amazon, Science, 303, 1337-1342, 2004.

Bachmeier, A. S. and Fuelberg, H. E.: A meteorological overview of the TRACE-A period, J. Geophys. Res., 101, 23 881-23 888, 1996.

Burpee, R. W.: The origin and structure of easterly waves in the lower troposphere of North Africa, J. Atmos. Sci., 29, 77-90, 1972.

Chaboureau, J. P., Tulet, P., and Mari, C.: Diurnal cycle of dust and cirrus over West Africa as seen from Meteosat Second Generation satellite and a regional forecast model, Geophys. Res. Lett, 34 , L02822, doi:10.1029/2006GL027771, 2007.

Chatfield, R., Vastano, J. A., Singh, H. B., and Sachse, G.: A general model of how fire emissions and chemistry produce African/oceanic plumes $\left(\mathrm{O}_{3}, \mathrm{CO}, \mathrm{PAN}\right.$, smoke $)$ in TRACE-A, J. Geophys. Res., 101, 24 279-24 306, 1996.

Chatfield, R. B., Guo, Z., Sachse, G. W., Blake, D. R., and Blake, N. J.: The subtropical global plume in the Pacific Exploratory Mission-Tropics A (PEM-Tropics A), PEM-Tropics B, and the Global Atmospheric Sampling Program (GASP): how tropical emissions affect the remote Pacific, J. Geophys. Res., 107,42784297, doi:10.1029/2001JD999497, 2002.

Crutzen, P. J. and Andreae, M. O.: Biomass burning in the tropics: impact on atmospheric chemistry and biogeochemical cycles, Science, 250, 1669-1678, 1990.

Delmas, R. A., Druilhet, A., Cros, B., Durand, P., Delon, C., Lacaux, J. P., Brustet, J. M., Serca, D., Affre, C., Guenther, A., Greenberg, J., Baugh, W., Harley, P., Klinger, L., Ginoux, P., Brasseur, G., Zimmerman, P. R., Gregoire, J. M., Janodet, E., Tournier, A., Perros, P., Marion, T., Gaudichet, A., Cachier, H., Ruellan, S., Masclet, P., Cautenet, S., Poulet, D., Biona, C. B., Nganga, D., Tathy, J. P., Minga, A., Loemba-Ndembi, J., Ceccato, P.: Experiment for Regional Sources and Sinks of Oxidants (EXPRESSO): An overview, J. Geophys. Res., 104, $30609-$ $30624,1999$.

Drummond, J. R. and Mand, G. S.: The Measurements of pollution in the troposphere (MOPITT) instrument: overall performance and calibration requirements, J. Atmos. Oceanic Technol. 13, 314-320, 1996.

Eck, T. F., Holben, B. N., Ward, D. E., Mukelabai, M. M., Dubovik, O., Smirnov, A., Schafer, J. S., Hsu, N. C., Piketh, S. J., Queface, A., Le Roux, J., Swap, R. J., and Slutsker, I.: Variability of biomass burning aerosol optical characteristics in southern Africa during the SAFARI 2000 dry season campaign and a comparison of single scattering albedo estimates from radiometric measurements, J. Geophys. Res., 108, 8477, doi:10.1029/2002JD002321, 2003.

Edwards, D. P., Halvorson, C., and Gille, J. C.: Radiative transfer modeling for the EOS Terra Satellite Measurement of Pollution in the Troposphere (MOPITT) instrument, J. Geophys. Res., 104, 
16755-16775, 1999.

Edwards, D. P., Lamarque, J.-F., Attié, J.-L., Emmons, L. K., Richter, A., Cammas, J.-P., Lyjak, L. V., Francis, G. L., Gille, J. C., and Drummond, J.R.: Tropospheric ozone over the tropical Atlantic: A satellite perspective, J. Geophys. Res., 108(D8), 4237, doi:10.1029/2002JD002927, 2003.

Emmanuel, K. A. and Zivkovìc-Rothman, M.: Development and evaluation of a convection scheme for use in climate models, J. Atmos. Sci., 56, 1766-1782, 1999.

Folkins, I., Chatfield, R., Baumgardner, D., and Proffitt, M.: Biomass burning and deep convection in southeastern Asia: Results from ASHOE/MAESA, J. Geophys. Res., 102, $13291-$ $13299,1997$.

Fromm, M. D. and Servranckx, R.: Transport of forest fire smoke above the tropopause by supercell convection, Geophys. Res. Lett., 30, 1542, 2003.

Giglio, L., Descloitres, J., Justice, C. O., and Kaufman, Y. J.: An enhanced contextual fire detection algorithm for MODIS, Remote Sens. Environ., 87, 273-282, 2003.

Giglio, L., Csiszar, I., and Justice, C. O.: Global distribution and seasonality of active fires as observed with the Terra and Aqua Moderate Resolution Imaging Spectroradiometer (MODIS) sensors, J. Geophys. Res, 111, G02016, doi:10.1029/2005JG000142, 2006.

Giglio, L.: Characterization of the tropical diurnal fire cycle using VIRS and MODIS observations, Remote Sensing of Env., 108, 407-421, 2007.

Hall, N. and Peyrillé, P.: Dynamics of the West African monsoon, J. Phys., IV France, 139, 85-103, 2006.

Houze, R. A. and Betts, A. K.: Convection in GATE, Rev. Geophys. Space Phys., 19, 541-576, 1981.

Ito, A. and Akimoto, H.: Seasonal and interannual variations in $\mathrm{CO}$ and $\mathrm{BC}$ emissions from open biomass burning in Southern Africa during 1998-2005, Glob. Biogeochem. Cy., 21(2), GB2011, doi:10.1029/2006GL028284, 2007.

Jacob, D. J., Heikes, B. G., Fan, S.-M., Logan, J. A., Mauzerall, D. L., Bradshaw, J. D., Singh, H. B., Gregory, G. L., Talbot, R. W., Blake, D. R., and Sachse, G. W.: Origin of ozone and $\mathrm{NO}_{\mathrm{x}}$ in the tropical troposphere: A photochemical analysis of aircraft observations over the South Atlantic basin, J. Geophys. Res., 101, 24 235-24 250, doi:10.1029/96JD00336, 1996.

Jacobson, M. K.: The short-term cooling but long-term warming due to biomass burning, J. Clim., 17, 2909-2926, 2004.

Jenkins, G. S., Mohr, K., Morris, V. R., and Arino, O.: The role of convective processes over the Zaire-Congo Basin to the southern hemispheric ozone maximum, J. Geophys. Res., 102, $18963-$ $18980,1997$.

Jonquières I., Marenco, A., Maalej, A., and Rohrer, F.: Study of ozone formation and transatlantic transport from biomass burning emissions over West Africa during the airborne tropospheric ozone campaigns TROPOZ I and TROPOZ II, J. Geophys. Res., 103, 19 059-19073, 1998.

Jourdain, L., Worden, H. M., Worden, J. R., Bowman, K., Li, Q., Eldering, A., Kulawik, S. S., Osterman, G., Boersma, K. F., Fisher, B., Rinsland, C. P., Beer, R., and Gunson, M.: Tropospheric vertical distribution of tropical Atlantic ozone observed by TES during the northern African biomass burning season, Geophys. Res. Lett., 34, L04810, doi:10.1029/2006GL028284, 2007.

Jost, C., Trentmann, J., Sprung, D., Andreae, M. O., McQuaid, J.
B., and Barjat, H.: Trace gas chemistry in a young biomass burning plume over Namibia: observations and model simulations, J. Geophys. Res., 108, 8482, doi:10.1029/2002JD002431, 2003.

Jost, H. J., Drdla, K., Stohl, A., Pfister, L, Loewenstein, M., Lopez, J. P., Hudson, P. K., Murphy, D. M., Cziczo, D. J., Fromm, M., Bui, T. P., Dean-Day, J., Gerbig, C., Mahoney, M. J., Richard, E. C., Spichtinger, N., Pittman, J. V., Weinstock, E. M., Wilson, J. C., Xueref, I.: In-situ observations of mid-latitude forest fire plumes deep in the stratosphere, Geophys. Res. Lett., 31, L11101, doi:10.1029/2003GL019253, 2004.

Justice, C. O., Giglio, L., Korontzi, S., Owens, J., Morisette, J. T., Roy, D. Descloitres, J., Alleaume, S., Petitcolin, F., and Kaufman, Y.: The MODIS fire products, Remote Sens. Environ., 83, 244-262, 2002.

Krishnamurti, T. N., Fuelberg, H. E., Sinha, M. C., Oosterhof, D., Bensman, E. L. and Kumar, V. B.: The meteorological environment of the tropospheric ozone maximum over the tropical South Atlantic Ocean, J. Geophys. Res., 98, 10 621-10 641, 1993.

Labonne, M., Bréon, F. M., and Chevallier, F.: Injection height of biomass burning aerosols as seen from a spaceborne lidar, Geophys. Res. Lett., 112, L11806, doi:10.1029/2007GL029311, 2007.

Mari, C. and Prospero, J.: African Monsoon Multidisciplinary Analysis-Atmospheric Chemistry (AMMA-AC): a new IGAC task; IGACtivities Newsletter, 31, 2-13, 2005.

Martin, R. V., Jacob, D. J., Logan, J. A., Bey, I., Yantosca, R. M., Staudt, A. C., Li, Q. B., Fiore, A. M. , Duncan, B. N. , Liu, H Y., Ginoux, P., and Thouret, V.: Interpretation of TOMS observations of tropical tropospheric ozone with a global model and in situ observations, J. Geophys. Res., 107, 4351, 2002.

Marenco, A., Medale, J. C., and Prieur, S.: Study of tropospheric ozone in the tropical belt (Africa, America) from STRATOZ and TROPOZ campaigns, Atmos. Environ., 24, 2823-2843, 1990.

Marufu, L., Dentener, F., Lelieveld, J., Andreae, M. O., and Helas, G.: Photochemistry of the African troposphere: influence of biomass-burning emissions, J. Geophys. Res., 105, 14513 14530, 2000.

Mason, S. A., Field, R. J., Yokelson, R. J., Kochivar, M. A., Tinsley, M. R., Ward, D. E., and Tao, W. M.: Complex effects arising in smoke plume simulations due to inclusion of direct emissions of oxygenated organic species from biomass combustion, J. Geophys. Res., 106, 12 527-12 539, 2001.

Mason, S. A., Trentmann, J., Winterrath, T., Yokelson, R. J., Christian, T. J., Carlson, L. J., Warner, T. R., Wolfe, L. C., and Andreae, M. O.: Intercomparison of two box models of the chemical evolution in biomass-burning smoke plumes, J. Atmos. Chem., 55, 273-297, 2006.

Matichuk, R. I., Colarco, P. R., Smith, J. A., and Toon, O. B.: Modeling the transport and optical properties of smoke aerosols from African savanna fires during the Southern African Regional Science Initiative campaign (SAFARI 2000), J. Geophys. Res., 112, D08203 doi:10.1029/2006JD007528, 2007.

Naik, V., Mauzerall, D. L., Horowitz, L. W., Schwarzkopf, M. D., Ramaswamy, V., and Oppenheimer, M.: On the sensitivity of radiative forcing from biomass burning aerosols and ozone to emission location, Geophys. Res. Lett., 34, L03818, doi:10.1029/2006GL028149, 2007.

Nicholson, S. E. and Grist, J.: The seasonal evolution of the atmospheric circulation over West Africa and Equatorial Africa, J. 
Clim., 16, 1013-1030, 2003.

Palacios-Orueta, A.,Parra, A., Chuvieco, E., and Carmona-Moreno, C.: Remote sensing and geographic information systems methods for global spatiotemporal modeling of biomass burning emissions: Assessment in the African continent, J. Geophys. Res., 109, D14S09, doi:10.1029/2004JD004734, 2004.

Pan, L., Gille, J. C., Edwards, D. P., Bailey, P. L., and Rodgers, C. D.: Retrieval of tropospheric carbon monoxide for the MOPITT experiment, J. Geophys. Res., 103, 32 277-32 290, 1998

Parker, D. J., Thorncroft, C. D., Burton, R. R., and Diongue, A.: Analysis of the African Easterly Jet using aircraft observations from the Jet2000 experiment, Q. J. R. Meteorol. Soc., 131, 14611482, 2005.

Pickering, K. E., Thompson, A. M., Scala, J. R., Tao, W. K., and Simpson, J.: Ozone distribution potential following convective redistribution of biomass burning emissions, J. Atmos. Chem., 14, 297-313, 1992.

Pickering, K. E., Thompson, A. M., Wang, Y., Tao, W.-K., McNamara, D. P. Kirchhoff, V. W. J. H., Heikes, B. G., Sachse, G. W., Bradshaw, J. D., Gregory, G. L., and Blake, D. R.: Convective transport of biomass burning emissions over Brazil during TRACE A, J. Geophys. Res., 101, 23 993-24 012, doi:10.1029/96JD00346, 1996.

Real, E., Law, K. S., Weinzierl, B., Fiebig, M., Petzold, A., Wild, O., Methven, J., Arnold, S., Strohl, A., Huntrieser, H., Roiger, A., Schlager, H., Stewart, D., Avery, M., Sachse, G., Browell, E., Ferrare, R., and Blake, D.: Processes influencing ozone levels in Alaskan forest fire plumes during long-range transport over the North Atlantic, J. Geophys. Res., 112(D10), D10S41, doi:10.1029/2006JD007576, 2007a.

Real, E., Law, K., Borrmann, S., Garnier, A., Cairo, F., Fierli, F., Orlandi, E., Schlager, H., Volk, M. and Minikin, A., Analyses of upper troposphere trace gases and aerosols measurements over West Africa during summer 2006, Proceedings of the 2nd AMMA International Conference, Karlshure, Germany, 26-30 November 2007, 364, 2007b.

Redelsperger, J. L., Diongue, A., Diedhiou, A., Ceron, J. P., Diop, M., Gueremy, J. F., and Lafore, J. P.: Multi-scale description of a Sahelian synoptic weather system representative of the West African monsoon, Q. J. R. Meteorol. Soc. 128, 582, 1229-1257 Part B, 2002.

Redelsperger, J. L., Thorncroft, C. D., Diedhiou, A., Lebel, T., Parker, D. J., and Polcher, J.: African Monsoon Multidisciplinary Analysis: An International Research Project and Field Campaign, BAMS, 87(12), 1739-1746, doi:10.1175/BAMS-8712-1739, 2006.

Reeves, C., Saunois, M., Mari, C., Murphy, J., Stewart, D., Mills, G., Oram, D., The distribution of tropospheric ozone during the West African Monsoon and its relationship to photochemical relevant tracers, Proceedings of the 2nd AMMA International Conference, Karlshure, Germany, 26-30 November 2007, 367, 2007.

Rosenfeld, D.: TRMM observed first direct evidence of smoke from forest fires inhibiting rainfall, Geophys. Res. Lett., 26, 31053108, 1999.

Saunois, M., Thouret, V., Mari, C., Corre, L., Picart, J., Mariscal, A., Nedelec, P., Minga, A., Solete, A., Agbangla, D., Characterisation of air masses over Cotonou during the wet season: influence of biomass burning and local pollution, Proceedings of the 2nd AMMA International Conference, Karlshure, Germany,
26-30 November 2007, 366, 2007.

Sauvage, B., Thouret, V., Cammas, J. P., Gheusi, F., Athier, G., and Nedelec, P.: Tropospheric ozone over Equatorial Africa: regional aspects from the MOZAIC data, Atmos. Chem. Phys., 5, 311335, 2005,

http://www.atmos-chem-phys.net/5/311/2005/.

Sauvage, B., Martin, R. V., van Donkelaar, A., and Ziemke, J. R.: Quantification of the factors controlling tropical tropospheric ozone and the South Atlantic maximum, J. Geophys. Res.Atmos., 112(D11), D11309, doi:10.1029/2006JD007831, 2007a.

Sauvage, B., Thouret, V., Cammas, J. P., Brioude, J., Nedelec, P., and Mari, C.: Meridional ozone gradients in the African upper troposphere, Geophys. Res. Lett., 34, L03817, doi:10.1029/2006GL028542, 2007b.

Sauvage, B., Gheusi, F., Thouret, V., Cammas, J. P., Duron, J. Escobar, J., Mari, C., Mascart, P., and Pont, V.: Medium-range midtropospheric transport of ozone and precursors over Africa: two numerical case-studies in dry and wet seasons, Atmos. Chem. Phys., 7, 5357-5370, 2007c, http://www.atmos-chem-phys.net/7/5357/2007/.

Sinha, P., Jaegl, L., Hobbs, P. V., and Liang, Q.: Transport of biomass burning emissions from southern Africa, J. Geophys. Res., 109, D20204, doi:10.1029/2004JD005044, 2004.

Stohl, A., Hittenberger, M., and Wotawa, G., Validation of the Lagrangian particle dispersion model FLEXPART against largescale tracer experiment data, Atmos. Environ., 32, 4245-4264, 1998a.

Stohl, A.: Computation, accuracy and applications of trajectories - A review and bibliography, Atmos. Environ., 32, 947-966, 1998 b.

Stohl, A. and Thomson, D. J.: A density correction for Lagrangian particle dispersion models, Bound-Lay Meteorol., 90, 1, 155167, 1999.

Stohl, A., Forster, C., Frank, A., Seibert, P., and Wotawa, G.: Technical note: The Lagrangian particle dispersion model FLEXPART version 6.2, Atmos. Chem. Phys., 5, 2461-2474, 2005, http://www.atmos-chem-phys.net/5/2461/2005/.

Stohl, A., Berg, T., Burkhart, J. F., Fjaeraa, A. M., Forster, C., Herber, A., Hov, O., Lunder, C., McMillan, W. W., Oltmans, S., Shiobara, M., Simpson, D., Solberg, S., Stebel, K., Strom, J., Torseth, K., Treffeisen, R., Virkkunen, K., and Yttri, K. E.: Arctic smoke - record high air pollution levels in the European Arctic due to agricultural fires in Eastern Europe in spring 2006, Atmos. Chem. Phys., 7, 511-534, 2007

Thompson, A. M., Doddridge, B. G., Witte, J. C., Hudson, R. D., Luke, W. T., Johnston, J. E., Johnston, B. J., Oltmans, S. J., and Weller, R.: A tropical Atlantic paradox: Shipboard and satellite views of a tropospheric ozone maximum and wave-one in January-February 1999, Geophys. Res. Lett., 27, 3317-3320, 2000.

Thompson, A. M., Witte, J. C., Hudson, R. D., Guo, H., Herman, J. R., and Fujiwara, M.: Tropical tropospheric ozone and biomass burning, Science, 291, 2128-2132, 2001.

Thorncroft, C. D. and Blackburn, M.: Maintenance of the African easterly jet, Quart. J. Roy. Meteorol. Soc., 125, 763-786, 1999.

Tompkins, A. M., Cardinali, C., Morcrette, J. J., and Rodwelll, M.: Influence of aerosol climatology on forecasts of the African Easterly Jet, Geophys. Res. Lett., 32, L10801, doi:10.1029/2004GL022189, 2005. 
Trentmann, J., Luderer, G., Winterrath, T., Fromm, M. D., Servranckx, R., Textor, C., Herzog, M., Graf, H. F., and Andreae, M. O.: Modeling of biomass smoke injection into the lower stratosphere by a large forest fire (Part I): reference simulation, Atm. Chem. Phys., 6, 5247-5260, 2006.

Wiedinmyer, C., Quayleb, B., Geronc, C., Belotea, A., McKenzied, D., Zhange, X., ONeillf, S., and Klos Wynnea, K.: Estimating emissions from fires in North America for air quality modeling Atmos. Environ., 40, 3419, 2006.
Yokelson, R. J., Bertschi, I. T., Christian, T. J., Hobbs, P. V., Ward, D. E., and Hao, W. M.: Trace gas measurements in nascent, aged and cloud-processed smoke from African savanna fires by airborne Fourier transform infrared spectroscopy (AFTIR), J. Geophys. Res., 108, 8478, doi:10.1029/2002JD002322, 2003.

Zhang, C., Woodworth, P., and Guojun, G.: The seasonal cycle in the lower troposphere over West Africa from sounding observations, Q. J. R. Meteorol. Soc., 132, 2559-2582, 2006. 